第 26 回獣医疫学会学術集会

教育講演

\title{
家畜における薬剤耐性菌のモニタリングと調査成績
}

浅井鉄夫*

農林水産省動物医薬品検査所

\section{Antimicrobial Resistance Monitoring Program in Food-Producing Animals in Japan}

\author{
Tetsuo ASAI* \\ National Veterinary Assay Laboratory, Ministry of Agriculture, Forestry and Fisheries, \\ 1-15-1 Tokura, Kokubunji, Tokyo 185-8511, Japan
}

\begin{abstract}
Summary
Antimicrobial agents are essential for human and animal health and welfare, but antimicrobial use can lead to antimicrobial resistance. The resistance arising from antimicrobial use in food-producing animals represents a potential hazard to human medicine through foodborne infection caused by resistant bacteria. In Japan, the Japanese Veterinary Antimicrobial Resistance Monitoring System (JVARM) was formed in 1999 in response to international concern about the impact of antimicrobial resistance on public health. In the JVARM program, initial monitoring for antimicrobial-resistant bacteria was carried out in 1999 and then the first and second stages of the JVARM program were completed in 2000-2003 and 2004-2007, respectively.

Veterinary antimicrobial use is a selective force for appearance and prevalence of antimicrobial-resistant bacteria in food-producing animals. However, antimicrobial-resistant bacteria are found in the absence of antimicrobial selective pressure. We show here the relationship between antimicrobial usage and prevalence of resistant bacteria under the JVARM from 1999 to 2007.
\end{abstract}

これまで半世紀以上にわたり，畜産現場において法的 規制の下で抗菌性物質が使用され，安全な畜産物の安定 した供給に貢献してきた。一方，医療や獣医療において使 用された抗菌性物質によって薬剤耐性菌が出現・増加し, 薬剤耐性菌による感染症は, 治療効果の低下につながる 深刻な問題となっている。

我が国では，家畜における薬剤耐性菌の実態と抗菌性 物質の使用状況の把握を目的に，1999年に家畜における 抗菌剂而性のモニタリングシステム（Japanese Veterinary Antimicrobial Resistance Monitoring System : JVARM）が

連絡先 : 浅井鉄夫*

農林水産省動物医薬品検査所抗生物質製剂検査室 干185-8511 東京都国分寺市戸倉 1-15-1

Tel : 042-321-1841 Fax : 042-321-1769

E-mail : asai-t@nval.go.jp
構築された。この中で, 全国 47 都道府県の家畜保健衛生 所等之農林水産省動物医薬品検査所及び（独）農林水産消 費安全技術センタ一肥飼料安全検査部が共同で，食品媒 介性病原体としてサルモネラとカンピロバクター, 薬剤 而性指標菌として大腸菌之腸球菌の 4 菌種を対象に耐性 菌の発現状況が調査されている。本講演では, JVARMの 調査で得られた成績に基づいて，我が国の家畜に㧍ける 抗菌剤の使用之耐性菌の出現・分布之の関連について紹 介する。

\section{1. 家畜における薬剤耐性菌の調査}

1968 年に英国で畜産および獣医療における抗生物質使 用に関する共同委員会が開催され，翌年にその報告書，い わゆる “スワン・レポート”が英国議会に提出された。こ の報告書が契機となって，家畜における抗菌性物質製剂及 
び抗菌性成長促進物質の使用々関連する薬剤而性菌問題 に, 各国が取り組むようになった。わが国でも，1976年に 「飼料の安全性の確保及び品質の安全に関する法律（飼料 安全法, 昭和 28 年法律第 35 号)」と 1979 年に「薬事法 (昭 和 35 年法律第 145 号)」が，それぞれ畜水産物への抗菌性 物質の残留や薬剤耐性菌に配慮して一部改正されている。

1990 年代に入り, WHO (世界保健機関), FAO (国連食 料農業機関), OIE (国際獣疫事務局) などの国際機関が 様々な薬剤而性菌に関する会議を開催してきた。WHOは 薬剤耐性菌に関する専門家会議（1997年：ベルリン, 1998 年 : ジュネーブ) を開催し, この中で, 薬剤耐性菌が 動物と人との間でどの程度分布し, 広がっているかとい う状況を把握するためのモニタリング（耐性菌の動向調 查之情報収集）の重要性が指摘された。また, OIE は, 各 国で実施している薬剤耐性菌の動向や抗菌性物質の使用 量についての畜産領域における調査方法を調和させると 共に，抗菌剤の慎重使用を励行していくため，薬剤耐性に 関する各種ガイドラインを策定した。

このような国際背景の中で, 国内では 1999 年に食用動 物（牛, 豚及び鶏）に打ける薬剤而性のモニタリングシステ ム (Japanese Veterinary Antimicrobial Resistance Monitoring System : JVARM）が構築された ${ }^{35)}$ 。現在, 全国 47 都道府 県の家畜保健衛生所等と農林水産省動物医薬品検査所及 び (独)農林水産消費安全技術センタ一肥飼料安全検査部 が共同で, 食品媒介性病原体としてサルモネラとカンピ ロバクター, 薬剂耐性指標菌として大腸菌と腸球菌の 4 菌種を対象に，健康な肥育牛，肥育豚，採卵彩鳥及びブロイ ラーにおける耐性菌の発現状況が調査されている。この 調査で得られた成績は, 食品安全委員会での薬剤耐性菌 の食品健康影響評価の審議に利用され, リスク評価結果 に基づくリスク管理対応に利用されていくこととなる。

1999～2007 年度までの過去 9 年間における健康家畜粪 便由来の調査株数は, 4 菌種合わせて 11,825 株である。調 査対象薬剂は, 各国のモニタリング状況, 薬剂の流通量と 抗菌作用機序に基づいて, $\beta$-ラク夕ム系, アミノグリコシ ド系, マクロライド系, テトラサイクリン系及びキノロン 系薬剤などが選定されている。これまで, 試行期 (1999 年 度)，第一期（2000～2003 年度)，第二期（2004～2007 年 度）が終了し, 現在第 3 期（2008 2009 年度, 予定）が行 われている。これまでの成績では, 概ねの薬剤で大きな耐 性率の変動は見られていない。

\section{2. 抗菌剂の使用と耐性菌の出現・分布}

抗菌性物質の使用による選択圧は，耐性菌の増加を引 き起こす最も重要な要因となる。しかし, 抗菌性物質は, 人や動物の健康を維持する上で, 重要な道具であり, その
使用には慎重を期さねばならない。家畜における抗菌性 物質の使用状況や耐性菌の発現状況は, 国・地域間で異 なるため, 薬剤耐性菌のリスク分析は, 各国・地域でのモ ニタリングデータに基づいて行われる必要がある。1999 年以降蓄積したモニタリング成績及びこれに関連した調 査研究成績に基づいて，(1)家畜に抗菌性物質を使用する 之耐性菌が増えるか，(2)家畜への抗菌性物質の使用を止 めると耐性菌が減少するか，(3)家畜に耐性菌が分布する 原因として何が重要か，という点について紹介する。

\section{（1）抗菌剂の使用と耐性菌の出現・分布}

\section{a. 概況}

国内の抗菌剤の動物別の使用量は，豚で際立って多く， 水産 (養殖), 肉用鶏の順となっている ${ }^{34)}$ 。カンピロバク ター, サルモネラ, 大腸菌及び腸球菌における耐性菌の発 現状況屯，豚や肉用鶏由来株で而性率が高く，牛や採卵鶏 由来株で低い傾向がある。

家畜で最む多く使用されているテトラサイクリン系薬 剂（TC）に対する耐性は，カンピロバクター，サルモネ ラ，腸球菌に扮いても高率に分布している $2,6,9,13,17,18$, 220,23, 25,31)。国内で病性鑑定材料から分離される各種病原細 菌においても TC 耐性は同様に認められる7,13,26,30)。動物 種ごとの各有効成分の推定使用量と薬剤耐性大腸菌の分 布を比べると，国内で使用量の多い系統の抗菌剤に対す る耐性菌が高頻度に出現している傾向が認められる6 た，病畜から分離された大腸菌の各種抗菌剤に対する耐 性率は，健康家畜の屯のに比べて高い ${ }^{13,30)}$ 。以上の様に， 薬剂耐性菌は, 各種疾病の治療に抗菌剂が使われること によって選択されていることが伺われる。

b. 交差耐性と共耐性

抗菌性物質の使用は，耐性菌の分布に影響を与えるが， その影響の程度は，薬剂耐性菌の耐性機構や多剂耐性菌 の状況により異なる。交差耐性（cross resistance）は，化 学構造や作用機序が類似している薬剤に対する耐性で, 耐性遺伝子の獲得や薬剤の標的部位の变異などにより引 き起こされる。一方で, 多剤而性菌は, 構造的に異なる薬 剂に対して耐性を示す（共耐性：co-resistance）ため，耐性 パターンに含まれるいずれかの薬剤が使用されることで 選択される（共選択 : co-selection）。このため，薬剤の使 用は使用された抗菌剂に対する而性と同時に，それ以外 の抗菌薬に対する耐性の分布に屯影響する。

家畜から分離されたカンピロバクターでは，マクロラ イド而性 C. coli は，主に標的部位の变異で，14，15 およ び 16 員環マクロライドに耐性を示す ${ }^{13)}$ 。このため，員環 数に関係なく耐性菌の選択に関与することが推察される。

サルモネラや大腸菌では，フルオロキノロン耐性株は， オールドキノロン耐性株の一部であるが，カンピロバク 
ターでは，オールドキノロン耐性株は，フルオロキノロン 耐性を示す $2,8,17,18)$ 。通常, サルモネラや大腸菌のオールド キノロン而性株では, GyrA のQRDRに1か所, フルオ ロキノロンに而性株では, GyrA の変異以外に ParC など に変異が認められる。しかし，カンピロバクターは, GyrAのQRDRに㧍ける1 加所の変異で，フルオロキ， ロン耐性を獲得する。したがって, フルオロキノロン耐性 カンピロバクターは，いずれかのキノロン剂の使用によ り選択される可能性が考えられる。

交差而性之共耐性の影響について，養豚場における抗 菌薬の使用状況と大腸菌の薬剤感受性試験成績を用いて 解析した ${ }^{14,15)}$ 。使用薬剂之同系統の薬剂に対する而性率の 上昇は，系統が異なる薬剤の使用による共選択の影響よ りも大きく, 而性菌の分布には, 共耐性より交差耐性の方 が強く影響する ${ }^{15)}$ 。その他，TC 系薬剤を使用した群では， TC 而性だけではなくアンピシリン (ABPC)，ストレプト マイシン（SM），カナマイシン（KM）打よびトリメトプ リム（TMP）而性が増加したが，PC 系薬剤を使用した群 では $\mathrm{ABPC}$ 及び TMP 而性，また，ST 合剤を使用した群 では TMP 而性のみ有意に増加した ${ }^{15)}$ 。このように，共選 択の影響の範囲および程度は，使用薬剂によって異なっ ていることが示唆されている。

\section{c. 菌種之血清型}

家畜由来細菌の薬剂耐性発現状況は, カンピロバク ター, サルモネラ, 大腸菌及び腸球菌で大きく異なってい $3^{2,6,9,13,17,18,20,23,25,31)}$ 。 TC や SM に対する而性率が調査し た薬剤の中で最も高いという傾向は，共通しているが，サ ルモネラの両薬剤に対する而性率は, 他の細菌に比べ極 めて高い。

カンピロバクターや腸球菌では，動物種により分離さ れる菌種に偏りが見られる。カンピロバクター食中毒の 大多数を占める $C$. jejuni は牛や鶏加ら分離され，豚から は C. coli が優勢に分離される ${ }^{17,18)}$ 。家畜由来株では，C jejuni の各種薬剤に対する耐性率は, C. coli に比べて低 $\left({ }^{17,18)}\right.$ 。また, 家畜由来腸球菌の主要な 3 菌種 (E. faecalis, E. faecieum 及び E. hirae) では, MIC 值の分布状況に違い が見られるため, 而性限界值 (ブレークポイント) は菌種 ごとに設定する必要がある。E. faecalis（主に豚，鶏）の耐 性率は, E. faecieum（主に牛, 豚, 鵎) や E. hirae（主に 牛, 豚)に比べて高(25)。

国内で牛や豚から分離されるサルモネラの主要な血清 型である Typhimurium では，1999～2001 年には，牛由来 株の $71.9 \%$ 及び豚由来株の $31.4 \%$ が DT 104 あるいは 104B とファージ型別されたが，2002 2005 年の分離株で は，牛由来株で $30.8 \%$ 及び豚由来株で $4.1 \%$ 之割合が低 下した ${ }^{10,21)}$ 。牛由来 Typhimurium の優勢な耐性パターン
が，ABPC-CP-SM-TC 耐性から ABPC-SM-KM-TC 耐性 に変動したため, CP 耐性が減少し，KM 而性が増加し た。豚では DSM-OTC 耐性株の割合が増加したため, $\mathrm{ABPC}$ 耐性及び CP 而性率が低下した ${ }^{21}$ 。鵎（特にブロイ ラー）で優勢な Infantis は， TC-SM 而性中心に KM 而性 や TMP 耐性を保有している5)。一方，サルモネラ食中毒 の主要な血清型である Enteritidisでは, 耐性発現は Typhimurium や Infantis に比べると低( ${ }^{99}$ 。このように, サルモネラの耐性率は，供試株の血清型やファージ型の 構成比が大きく影響する。

その他の細菌においても, 血清型による耐性率の違いが 認められている。Pener 法で B，D，G 及び Y 群に型別さ れたC. jejuni を用いて，5 薬剤（ABPC, SM, TC, CP 及び ERFX）に対する耐性を比較したところ，G 群の ABPC 耐 性率（約 70\%）が他の 3 群に比べて高いむのであった また，騨大腸菌症から分離された E. coli では，O78 株で ERFX 耐性が多く認められている30)。

したがって, 薬剤感受性調査の成績を検討する場合, 菌 種や血清型により耐性発現状況に違いが認められること を十分に考慮する必要がある。

\section{3. 休薬後の耐性菌の分布}

各国で飼料添加物としてされていたアボパルシンは, バンコマイシンに化学構造がよく似た抗生物質で, バン コマイシン而性腸球菌（VRE）の出現要因として 1990 年 代の終わりに使用が禁止された。しかし，1995 年にアボ パルシンを禁止したデンマークでは，VRE は減少しつつ 屯，数年にわたり継続的に分離されていた（http://www. danmap.org/)。

CP は広域なスペクトルを有することから，動物用医薬 品として畜産分野で広く使用されていた。その後，CP は 人に対して再生不良性貧血などの副作用を引き起こすこ とが明らかとなり，わが国では 1998 年に食用動物に対す る使用が中止されている。

1999 年に健康動物から分離された CP 而性大腸菌は, 牛由来株では $3.1 \%$ で, 豚由来株では $22.3 \%$ であった ${ }^{23)}$ 。

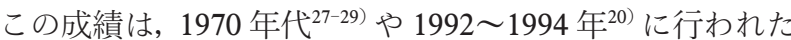
全国調査の成績と比べて，牛では明らかに減少している が，豚では大きな変動は見られていない。現在む， CP と 同系等の薬剤であるチアンフェニコール（TP） やフロル フェニコール（FFC）が使用されているが, FFC の流通量 はTPに比べて少ない。TPの大部分は豚で使用されてい ることから，豚に抢ける CP 耐性の分布には交差耐性が 影響したと考えられる12)。

一方, 病畜由来大腸菌では健康畜由来大腸菌に比へ, 牛, 豚ともに高い CP 耐性が分布している ${ }^{11)}$ 。牛由来 $\mathrm{CP}$ 
而性株では ABPC, DSM, OTC および TMP 而性, 豚由来 CP 耐性株では DSM および TMP 而性を保有していたこ とから, CP 使用中止後においても CP 耐性が分布する原 因として, 疾病治療への抗菌性物質の使用による共選択 が関与していると考えられる ${ }^{12)} 。$

CP 而性は, CP 中止後 10 年経過した 2007 年度にも依 然として分布している。多剂耐性菌の耐性パターンに含 まれている耐性菌のコントロールは, 極めて難しい問題 といえる。

\section{4. 家畜に耐性菌が分布する要因}

家畜に抢ける薬剤耐性菌の分布には, 家畜への抗菌性 物質の使用が様々な形で関与することが理解できよう。 しかし, 家畜の間, 特に肉用鶏では, 動物用抗菌性物質製 剤や抗菌性飼料添加物の承認・許可されていない成分に 対する而性菌が分離されている。例えば, 肉用鶏由来の大 腸菌 ${ }^{24)}$ やサルモネラ (未発表) の中に, セフチオフルなよ゙ の第 3 世代セファロスポリンに対する耐性菌が存在する。 セファロスポリン系抗菌性物質は, 家畜では牛と豚では 承認された薬剤があるが, 飼料添加物としては許可され ていない。

国内で肉用鶏や鶏肉から分離される $S$. Infantis は TC と SM に対して耐性を示す株が多いことが知られている が, テトラサイクリンやストレプトマイシンは肉用䳕農 場であまり利用されていないし，我々の調査においても， 耐性パターンに含まれる薬剤は, 耐性株が分離された農 場でほとんど使用されていない1)。また，遡り調査で 1997 年頃から国内の肉用鵎農場で広範に浸潤した耐性型と遺 伝子型の類似株が，1993 年の肉用鷱由来株で認められて いる4。このタイムラグや広域に拡散した要因については 不明であるが， TC-SM 而性 S. Infantis が長期間分布する 原因として細菌の定着性などが推察される4)。

フルオロキノロン耐性 C. jejuni が分離された 44 農場 及びC. coli が分離された 58 農場で, フルオロキノロン剂 を使用していた農場は 2 農場及び 1 農場のみであった3)。 また，フルオロキノロン耐性 C. jejuni が分離された 2 農 場で追跡調查を実施したが, 薬剤使用とは関連しない耐 性株の出現や耐性株の入替りが確認され, 薬剤耐性菌の 感染環の存在が示された ${ }^{19)}$ 。過去に扔いてフルオロキノ ロン剤が使用されたことによって，フルオロキノロン耐 性カンピロバクターが出現した可能性は否定できないが, 農場におけるフルオロキノロン耐性株の分布には現状の 使用状況を必ずしも反映しているわけではないことが示 されている。

近年, 国内の家畜においてもセファロスポリン耐性サル モネラが分離されている。牛から Newportや Typhimurium
(秋葉ら，私信），鶏から Infantis や Senftenberg などの血 清型 (未発表)で, セファロスポリン耐性遺伝子 (blaCMY2 やblaCTX-M-2）汃確認されている。牛から分離された Newport や Typhimurium では, PFGE型や耐性遺伝子 コードするプラスミドは, 海外で報告されているタイプ と類似している。このことは, 多剤耐性サルモネラが, 海 外から何らかのルートで国内に侵入し, 拡散した可能性 を強く示唆している。海外加の耐性菌や耐性遺伝子の 浸入については，現状では十分な取り組みがなされてい るとはいえない。

このように，抗菌薬による選択圧のない状況下におい ても, 細菌の定着性, 而性菌の感染環により, 而性菌が発 現・維持されている可能性が示唆されている。

\section{5. 最後に}

食用動物に分布する薬剂而性菌は，畜産物を介して直 接的又は間接的に食品媒介性感染症を引き起こす可能性 がある。この問題は，いわゆる “食中毒菌”の屯のと類似 しており，そのコントロールとして食肉, 騨卵及び乳製品 の生産・流通過程における衛生対策で改善する部分む 多々ある。一方で, 食用動物に分布する薬剤而性菌のコン トロールは, 獣医師に与えられた重要な使命之いえる。獣 医師は, 獣医療現場で様々な疾病の治療に抗菌性物質を 投与してきた。近年の風潮は, 獣医師の治療行為に対して 一石を投じたものといえよう。食用動物における薬剤耐 性菌の増加を防止するため, 抗菌剤の「慎重使用」は，耐 性菌問題に対するリスク管理手法として国際的な共通認 識となっている33)。獸医師は, 細菌感染症に対する「魔法 の弾丸」を失うことのないよう，抗菌剤の慎重使用に努め ていかなければならない。今後, 而性分布に影響を及ぼす 因子について様々な角度からの解析が望まれる。

\section{引用文献}

1）浅井鉄夫，JVARM に招ける抗菌剂の使用之耐性との 関係解析について, 抗菌剤研究会報, 27, 10-16, 2005.

2) Asai, T., et al., Antimicrobial resistance in Salmonella isolates from apparently healthy food-producing animal from 2000 to 2003 : the first stage of Japanese Veterinary Antimicrobial Resistance Monitoring (JVARM). J. Vet. Med. Sci. 68, 881-884, 2006.

3) Asai, T., et al., Association of antimicrobial resistance in Cmapylobacter isolated from food-producing animals with antimicrobial use on farms. Jpn. J. Infect. Dis. 60, 290-294, 2007.

4) Asai, T., et al., Long-term prevalence of antimicrobialresistant Salmonella enterica subspecies enterica serovar 
Infantis in broiler chicken industry in Japan. Microbiol Immunol. 51, 111-115, 2007.

5) Asai, T., et al., Antimicrobial resistance types and genes in Salmonella enterica Infantis isolates from retail raw chicken meats and broiler chicken on farms. J. Food Protect. 69, 214-216, 2006.

6) Asai, T., et al., Correlation between the usage volume of veterinary therapeutic antimicrobials and resistance in Escherichia coli isolated from the feces of foodproducing animals in Japan. Jpn J Infect Dis. 58, 369372, 2005.

7) Esaki, H., et al., Antimicrobial susceptibility of Mannheimia haemolytica isolates from cattle in Japan from 2001 to 2002. J Vet Med Sci. 67, 75-77, 2005.

8) Esaki, H., et al., Comparison of fluoroquinolone resistance genes of Salmonella enterica serovar Choleraesuis isolates in Japan and Taiwan. Jpn J Infect Dis. 57, 287288, 2004.

9) Esaki, H., et al., Antimicrobial susceptibility of Salmonella isolated from cattle, swine and poultry (20012002) : report from the Japanese Veterinary Antimicrobial Resistance Monitoring Program. J Antimicrob Chemother. 53, 266-270, 2004.

10) Esaki, H., et al., Epidemiological characterization of Salmonella Typhimurium DT104 prevalent among food-producing animals in the Japanese veterinary antimicrobial resistance monitoring program (1999-2001). Microbiol Immunol. 48, 553-556, 2004.

11) Harada, K., et al., Antimicrobial susceptibility of pathogenic Escherichia coli isolated from the sick cattle and pigs in Japan. J Vet Med Sci. 67, 999-1003, 2005.

12) Harada, K., et al., T. Role of co-resistance in the development of chloramphenicol resistance in Escherichia coli isolated from sick cattle and pigs. Am. J. Vet. Res. 67, 230-235, 2006.

13) Harada, K., et al., Characterization of macrolideresistant Campylobacter coli isolates from food-producing animals on farms across Japan during 2004. J. Vet. Med. Sci. 68, 1109-1111, 2006.

14) Harada, K., et al., T. 2007. Contribution of multiantimicrobial resistance to the population of antimicrobial resistant Escherichia coli isolated from apparently healthy pigs in Japan. Microbiol. Immunol. 51, 493-499, 2007.

15) Harada, K., et al., Farm-level impact of therapeutic antimicrobial use on antimicrobial-resistant populations of Escherichia coli isolates from pigs. Microb. Drug Resist. 14, 239-44.

16) Harada, K., et al., Serotypes and antimicrobial susceptibilities of Campylobacter jejuni isolates from cattle, layers and broilers in Japan. Microbiol Immunol. (in press).

17) Ishihara, K,. et al., Y. Antimicrobial susceptibilities of Campylobacter isolated from food-producing animals on farms (1999-2001) : results from the Japanese Veterinary Antimicrobial Resistance Monitoring Program. Int. J. Antimicrob. Agents. 24, 261-267, 2004.

18) Ishihara, K., et al., Comparison of Campylobacter isolated from humans and food-producing animals in Japan. J. Appl. Microbiol. 100, 153-160, 2006.

19) Ishihara, K., et al., The dynamics of antimicrobialresistant Campylobacter jejuni on Japanese broiler farms. J. Vet. Med. Sci. 68, 515-518, 2006.

20）石丸雅敏, 遠藤裕子, 吉村治郎. 1992 1994 年に家畜 家禽から分離された大腸菌, サルモネラ及び黄色ブ ドウ球菌の各種抗菌剂に対する薬剤耐性. 動物医薬 品検査所年報 33, 1-20, 1996.

21) Kawagoe, K., et al., Changes of multi-drug resistance pattern in Salmonella enterica subspecies enterica serovar Typhimurium isolates from food-producing animals in Japan. J. Vet. Med. Sci. 69, 1211-1213, 2007.

22) Kijima-Tanaka, M., et al., A national surveillance of Shiga toxin-producing Escherichia coli in food-producing animals in Japan. J. Vet. Med. B. 52, 230-237, 2005.

23) Kijima-Tanaka, et al., A national surveillance of antimicrobial resistance in Escherichia coli isolated from food-producing animals in Japan. J. Antimicrob. Chemother. 51, 447-451, 2003.

24) Kojima, A., et al., Extended-spectrum-beta-lactamaseproducing Escherichia coli strains isolated from farm animals from 1999 to 2002 : report from the Japanese Veterinary Antimicrobial Resistance Monitoring Program. Antimicrob. Agents Chemother. 49, 3533-3537, 2005.

25) Kojima, A., et al., Classification and antimicrobial susceptibilities of Enterococcus species isolated from apparently healthy food-producing animals in Japan. Zoonoses Public Health (in press)

26) Morioka, A., et al., In vitro activity of 24 antimicrobial agents against Staphylococcus and Streptococcus isolated from diseased animals in Japan. J. Vet. Med. Sci. 67, 207-210, 2005. 
27）中村政幸，大前憲一，小枝徹雄. 1976 年に分離した 牛, 豚由来大腸菌の薬剤耐性および $\mathrm{R}$ プラスミドの 分布. 動物医薬品検査所年報 15，21-27，1978.

28）中村政幸ら，1977 年に分離した牛，豚由来大腸菌の 薬剂而性および $\mathrm{R}$ プラスミドの分布. 動物医薬品検 査所年報 16, 31-37, 1979 .

29）大前憲一, 米沢昭一, 寺門誠致. 家畜由来大腸菌のス トレプトマイシン耐性形質と $\mathrm{R}$ プラスミド。動物医 薬品検査所年報 17, 23-29, 1980.

30) Ozawa, M., et al., Antimicrobial susceptibilities, serogroups and molecular characterization of avian pathogenic Escherichia coli isolates in Japan. Avian Dis. 52, 392-396.

31）高橋敏雄ら, 家畜衛生分野における耐性菌の現状と今
後の課題. 感染症学雑誌 80, 185-195, 2006.

32) Takahashi, T., et al., Emergence of fluoroquinolone resistance in Campylobacter jejuni in chickens exposed to enrofloxacin treatment at the inherent dosage licensed in Japan. J. Vet. Med. B. 52, 460-464, 2005.

33）田村 豊. OIE 薬剤耐性ガイドラインの概要. 日本獣 医師会誌 55，430-434， 2002.

34）田村 豊. 動物用抗菌剂の使用動向之薬剤耐性菌対 策一特に臨床獣医師の果たす役割について一。日本 獣医師会誌 56，685-691， 2003.

35) Tamura, Y., The Japanese veterinary antimicrobial resistance monitoring system (JVARM). OIE international standards on antimicrobial resistance, 2003. pp. 206-210. 